\section{Research Article}

\section{Check for updates}

\section{OPEN ACCESS}

\section{Received: Mar 17, 2020}

Revised: Apr 28, 2020

Accepted: May 4, 2020

Souza GL, Moura CCG, Silva ACA, Marinho JZ, Silva TR, Dantas NO, Bonvicini JFS, Turrioni AP

*Correspondence to

Camilla Christian Gomes Moura, PhD

Adjunct Professor, Department of

Endodontics, School of Dentistry, Federal

University of Uberlândia, Av Pará 1720, Campus

Umuarama, Block 4L, annex A, Uberlândia

38405-328, Brazil.

E-mail: camillamoura@ufu.br

Copyright (c) 2020. The Korean Academy of

Conservative Dentistry

This is an Open Access article distributed under the terms of the Creative Commons Attribution Non-Commercial License (https:// creativecommons.org/licenses/by-nc/4.0/) which permits unrestricted non-commercial use, distribution, and reproduction in any medium, provided the original work is properly cited.

\section{Funding}

The research was financed in part by the Coordenação de Aperfeiçoamento de Pessoal de Nível Superior - Brasil (CAPES) - Finance Code 001, FAPEMIG and CNPq.

Conflict of Interest

No potential conflict of interest relevant to this article was reported.

\title{
Effects of zinc oxide and calcium-doped zinc oxide nanocrystals on cytotoxicity and reactive oxygen species production in different cell culture models
}

\section{Gabriela Leite de Souza (D),' Camilla Christian Gomes Moura (D), ${ }^{*}$ Anielle Christine Almeida Silva (10), ${ }^{2}$ Juliane Zacour Marinho (10, ${ }^{3}$ Thaynara Rodrigues Silva $\left(\mathbb{D},{ }^{1,2}\right.$ Noelio Oliveira Dantas $\mathbb{1},^{2}$ Jéssica Fernanda Sena Bonvicini $\left(\mathbb{0},{ }^{4}\right.$ Ana Paula Turrioni $\left(\mathbb{C}^{4}\right.$}

'Department of Endodontics, School of Dentistry, Federal University of Uberlândia, Uberlândia, MG, Brazil ${ }^{2}$ Functional and New Nanostructured Materials Laboratory, Physics Institute, Federal University of Alagoas, Maceió, AL, Brazil

${ }^{3}$ Institute of Chemistry, Federal University of Uberlândia, Uberlândia, MG, Brazil

${ }^{4}$ Department of Pediatric Dentistry, School of Dentistry, Federal University of Uberlândia, Uberlândia, MG, Brazil

\section{ABSTRACT}

Objectives: This study aimed to synthesize nanocrystals (NCs) of zinc oxide ( $\mathrm{ZnO}$ ) and calcium ion $\left(\mathrm{Ca}^{2+}\right)$-doped $\mathrm{ZnO}$ with different percentages of calcium oxide $(\mathrm{CaO})$, to evaluate cytotoxicity and to assess the effects of the most promising NCs on cytotoxicity depending on lipopolysaccharide (LPS) stimulation.

Materials and Methods: Nanomaterials were synthesized $(\mathrm{ZnO}$ and $\mathrm{ZnO}: \mathrm{xCa}, \mathrm{x}=0.7 ; 1.0$; 5.0; 9.0) and characterized using X-ray diffractometry, scanning electron microscopy, and methylene blue degradation. SAOS-2 and RAW 264.7 were treated with NCs, and evaluated for viability using the MTT assay. NCs with lower cytotoxicity were maintained in contact with LPS-stimulated (+LPS) and nonstimulated (-LPS) human dental pulp cells (hDPCs). Cell viability, nitric oxide (NO), and reactive oxygen species (ROS) production were evaluated. Cells kept in culture medium or LPS served as negative and positive controls, respectively. One-way analysis of variance and the Dunnett test $(\alpha=0.05)$ were used for statistical testing. Results: $\mathrm{ZnO}: 0.7 \mathrm{Ca}$ and $\mathrm{ZnO}: 1.0 \mathrm{Ca}$ at $10 \mu \mathrm{g} / \mathrm{mL}$ were not cytotoxic to SAOS-2 and RAW 264.7. +LPS and -LPS hDPCs treated with $\mathrm{ZnO}, \mathrm{ZnO}: 0.7 \mathrm{Ca}$, and $\mathrm{ZnO}: 1$.0Ca presented similar NO production to negative control $(p>0.05)$ and lower production compared to positive control $(p<0.05)$. All NCs showed reduced ROS production compared with the positive control group both in +LPS and -LPS cells $(p<0.05)$. Conclusions: NCs were successfully synthesized. $\mathrm{ZnO}, \mathrm{ZnO}$ :0.7Ca and $\mathrm{ZnO}$ :1.0Ca presented the highest percentages of cell viability, decreased ROS and NO production in +LPS cells, and maintenance of NO production at basal levels.

Keywords: Cell survival; Nanoparticles; Zinc oxide 


\section{Author Contributions}

Conceptualization: Souza GL, Moura CCG, Turrioni AP; Data curation: Souza GL, Silva ACA, Marinho JZ; Formal analysis: Souza GL, Dantas NO, Silva ACA, Moura CCG, Turrioni AP; Funding acquisition: Turrioni AP, Moura CCG, Silva ACA, Dantas NO; Investigation: Souza GL, Marinho JZ, Silva TR, Bonvicini JFS; Methodology: Souza GL, Marinho JZ, Silva TR, Bonvicini JFS; Project administration: Moura CCG; Resources: Moura CCG, Silva ACA, Dantas NO, Turrioni AP; Software: Souza GL, Silva ACA, Marinho JZ, Silva TR, Bonvicini JFS; Supervision: Moura CCG; Validation: Souza GL, Moura CCG, Turrioni AP; Visualization: Souza GL, Moura CCG, Turrioni AP; Writing - original draft: Souza GL, Moura CCG, Silva ACA, Marinho JZ, Silva TR, Dantas NO, Bonvicini JFS, Turrioni AP; Writing - review \& editing: Souza GL, Moura CCG.

ORCID iDs

Gabriela Leite de Souza (ID

https://orcid.org/0000-0003-3505-5258

Camilla Christian Gomes Moura (D)

https://orcid.org/0000-0002-5653-8403

Anielle Christine Almeida Silva (D)

https://orcid.org/0000-0002-5274-156X

Juliane Zacour Marinho (D)

https://orcid.org/0000-0002-7865-9409

Thaynara Rodrigues Silva (D)

https://orcid.org/0000-0003-1302-5525

Noelio Oliveira Dantas (iD)

https://orcid.org/0000-0001-6752-7382

Jéssica Fernanda Sena Bonvicini (D)

https://orcid.org/0000-0002-7166-8572

Ana Paula Turrioni $\mathbb{D}$

https://orcid.org/0000-0002-6387-7411

\section{INTRODUCTION}

Vital pulpal therapy (VPT) is an alternative to endodontic treatment to maintain pulpal vitality [1]. This technique preserves the vitality of the remaining pulp and promotes the formation of new dentin to cover the exposed pulp. In clinical practice, the term VPT is used to describe direct or indirect pulp capping procedures, in which a cover material is applied to the exposed pulp or dentin, respectively, or pulpotomy, which involves removal of the coronary pulp followed by direct coverage of the remaining pulp tissue [1].

Nanotechnology has enabled the production of dental materials on a nanometric scale, with improved physicochemical properties. The development of nanoparticles (NPs) for medical purposes has been widely investigated, since when the size is greatly reduced at the nanometric scale, the surface-to-volume ratio increases, which generates new and interesting properties, such as a greater ability to absorb drugs, probes, and proteins [2-4]. In addition to size and shape, crystalline NPs show alterations in both physical and biological properties [5]. The size reduction provides better bioavailability in comparison to bulk material, improving the absorption of NPs in biological systems [6,7]. However, nanomaterials can interact with cellular components and induce cytotoxic effects, since proteins and cellular components range in size between 5 and $50 \mathrm{~nm}$ [8].

Zinc oxide $(\mathrm{ZnO})$ has been widely used as an endodontic filling material [9] and in pulpotomy [10] for primary teeth. $\mathrm{ZnO}$ has been shown, in its natural form, to reduce the activity of a wide variety of bacteria [11], and its NP form improves its profile [12]. One strategy to change the properties of NPs and, therefore, their environmental implications, is the doping technique [13]. Doping involves the intentional modification of the composition of NPs by the addition of dopants (impurities), with the intention of improving their functionality or reducing undesirable properties $[14,15]$. Many agents have been suggested for the doping of $\mathrm{ZnO} N \mathrm{NPs}$ [14]. Among them, calcium doping of $\mathrm{ZnO}(\mathrm{ZnO}: \mathrm{Ca})$ has been shown to attenuate strain in the cell unit [16] and to improve antibacterial activity [14,17]. Considering that calcium hydroxide $\left(\mathrm{Ca}(\mathrm{OH})_{2}\right)$ is a regenerative material that is widely used in VPT to induce the formation of mineralized tissue, it would be interesting to evaluate the association between calcium and $\mathrm{ZnO}$ in the NP form using the doping technique.

In this study, pure $\mathrm{ZnO}$ and $\mathrm{Ca}^{2+}$-doped $\mathrm{ZnO}(\mathrm{ZnO}: \mathrm{xCa})$ nanocrystals ( $\mathrm{NCs}$ ) were synthesized with different percentages of $\mathrm{Ca}^{2+}$ by weight $(\mathrm{x}=0.7 \% ; 1.0 \% ; 5.0 \% ; 9.0 \%)$, and the chemistry and physical properties and cytotoxicity were assessed in a human osteosarcoma cell line (SAOS-2) and a leukemia macrophage murine cell line (RAW 264.7). Subsequently, the NCs that provided the most promising results were placed in contact with human dental pulp cells (hDPCs) that were stimulated or nonstimulated with lipopolysaccharide (LPS) to evaluate the cytotoxic effects and modulatory capacity of reactive oxygen species (ROS) production by these cells. The null hypothesis was that the different NCs tested would not affect SAOS-2, RAW 264.7, and hDPC responses.

\section{MATERIALS AND METHODS}

\section{Synthesis and characterization of nanocomposites of Ca-doped ZnO and calcium oxide ( $\mathrm{CaO}) \mathrm{NCs}$}

$\mathrm{ZnO}$ NCs were synthesized via coprecipitation based on Silva et al. [14]. The $\mathrm{Ca}^{2+}$-doped $\mathrm{ZnO}$ nanocomposites were synthesized by coprecipitation using a solution of calcium 
chloride ( $\geq 99.9 \%$ ) (Sigma-Aldrich, St. Louis, MO, USA) in a concentration of $\mathrm{x}$ wt. $\% \mathrm{Ca}$ in relation to zinc ( $\mathrm{x}=0.7 \% ; 1.0 \% ; 5.0 \%$; $9.0 \%$ ) during the reaction of ZnO NCs [14]. X-ray diffractometry (XRD) measurements were performed on a SHIMATZU diffractometer XDR6000 operated at $20 \mathrm{kV}$ and $2 \mathrm{~mA}$ with CuK radiation $(\lambda=1.5406 \AA)$ in the powder samples. Scanning electron microscopy (SEM) images were obtained using an electronic microscope with energy dispersive X-ray spectrometry (EDS) (Zeiss EVO MA10, Carl Zeiss, Oberkochen, Germany) of the powder samples. The photocatalytic activity of the samples was tested by the degradation of methylene blue (MB) under artificial light irradiation, with a $300 \mathrm{~W}$ Xenon lamp as the light source. In detail, $8 \mathrm{mg}$ of photocatalyst was added to $50 \mathrm{~mL}$ of $\mathrm{MB}$ solution $(0.02 \mathrm{mmol} / \mathrm{L})$ in a cylindrical reactor. A magnetic stirrer was used to ensure the homogeneous dispersion of the photocatalyst during the reaction. The photocatalytic reactor was positioned $15 \mathrm{~cm}$ below the light source, and the photocatalytic reaction was initiated by adding the catalyst into the reactor and switching on the lamp. At controlled intervals, $1.0 \mathrm{~mL}$ suspensions were collected for analysis. Adsorption experiments were conducted under the same conditions but without xenon light irradiation. The MB concentration was measured using an ultraviolet-visible-near- infrared (UV-VIS-NIR) spectrophotometer (Shimadzu, Kyoto, Japan) at a wavelength of $663 \mathrm{~nm}$. The percentage of discoloration was calculated using the following formula: $\%$ Discoloration $=1-\left(\mathrm{A} / \mathrm{A}_{\mathrm{o}}\right) \times 100(1)$, where $\mathrm{A}$ is the absorbance of the solution at time $(t)>0$, and $A_{o}$ is the initial absorbance.

\section{RAW 264.7/SAOS-2 cell culture and nanocomposite treatment}

RAW 264.7 and SAOS-2 were obtained from the Cell Bank of Rio de Janeiro (Rio de Janeiro, RJ, Brazil). Cells were cultured until confluence in Dulbecco's Modified Eagle's Medium (DMEM) (Vitrocell Embriolife, Campinas, SP, Brazil) supplemented with 10\% heat-inactivated fetal bovine serum (FBS) (Gibco, Langley, OK, USA) and 1\% penicillin-streptomycin (SigmaAldrich), in a humid atmosphere of $5 \% \mathrm{CO}_{2}$ and $37^{\circ} \mathrm{C}$. RAW 264.7 and SAOS-2 cells were plated in quintuplicate in 96-well plates (Costar Corp., Cambridge, MA, USA) $\left(2 \times 10^{4}\right.$ cells/well) and allowed to adhere overnight. The cells were then stimulated with autoclaved solutions of (a) $\mathrm{ZnO}$, (b) $\mathrm{ZnO}: 0.7 \mathrm{Ca}$, (c) $\mathrm{ZnO}: 1.0 \mathrm{Ca}$, (d) $\mathrm{ZnO}$ :5.0Ca and (e) ZnO:9.0Ca at concentrations of 10 $\mu \mathrm{g} / \mathrm{mL}, 50 \mu \mathrm{g} / \mathrm{mL}$, and $100 \mu \mathrm{g} / \mathrm{mL}$ in fresh medium for 24 hours. The control group contained cells maintained in culture medium (DMEM). After the incubation period, the cells were prepared for cell viability analysis by the MTT formazan viability assay. This study was repeated twice using 5 samples for each group at every time point.

\section{hDPC cell culture}

Primary hDPC cultures were donated from the Faculty of Dentistry of the Federal University of Uberlândia (Ethics Committee protocol number 2019/54488816.2.0000.5152). Two healthy primary molar teeth $(\mathrm{n}=2)$ were collected from 2 patients ( 2 males aged 10-11) after their guardians signed the informed consent form. The teeth were collected, placed inside a Falcon tube with DMEM (Vitrocell Embriolife) and immediately taken to the Biomaterials and Cell Biomaterials Laboratory. The pulp was extracted from the interior of the pulp chamber using a previously sterilized sharp dentin spoon and immersed for 1 hour in a solution of $3 \mathrm{mg} / \mathrm{mL}$ collagenase type I (Sigma-Aldrich) and $4 \mathrm{mg} / \mathrm{mL}$ dispase (Sigma-Aldrich). The solution was centrifuged at 1,200 rpm for 2 minutes and resuspended in basal medium. The obtained cells were plated in $25 \mathrm{~cm}^{2}$ flasks and cultivated using DMEM (Vitrocell Embriolife) supplemented with 10\% heat-inactivated FBS (Gibco) and 1\% penicillin-streptomycin (Sigma-Aldrich). The cells were incubated for 4 days in a humid atmosphere of $5 \% \mathrm{CO}_{2}$ and $37^{\circ} \mathrm{C}$. The culture medium was first replaced after 3 days of incubation, and thereafter, it was changed twice a week. The cells were expanded up to the fourth passage, stored in cryogenic medium of FBS 
and 10\% dimethyl sulfoxide (DMSO) (LGC Biotecnologia, Cotia, SP, Brazil), and frozen in liquid nitrogen for later experimental use [18].

\section{hDPCs lipopolysaccharide-induced stress and NC treatment}

The working concentration for use in hDPC cultures was established based on the best results regarding cell viability obtained in preliminary tests using SAOS-2 and RAW 264.7. Cells were cultured until confluence in DMEM (Vitrocell Embriolife) supplemented with $10 \%$ heat-inactivated FBS (Gibco) and 1\% penicillin-streptomycin (Sigma-Aldrich), in a humid atmosphere of $5 \% \mathrm{CO}_{2}$ and $37^{\circ} \mathrm{C}$. hDPCs were plated in quintuplicate in 96-well plates (Costar Corp.) $\left(2 \times 10^{4}\right.$ cells/well $)$ and allowed to adhere overnight. In half of the samples, the culture medium was replaced with DMEM (Vitrocell Embriolife) without FBS, and the cells were stimulated with the autoclaved (a) $\mathrm{ZnO}$, (b) $\mathrm{ZnO}: 0.7 \mathrm{Ca}$, and (c) $\mathrm{ZnO}$ :1.0Ca solutions at concentrations of $10 \mu \mathrm{g} / \mathrm{mL}$ (cells without stimulation of LPS: -LPS). The remaining samples were incubated with the NCs and LPS (LPS, ultra-pure grade, Escherichia coli O111: B4, Invitrogen, San Diego, CA, USA) at a concentration of $10 \mu \mathrm{g} / \mathrm{mL}$ (cells with stimulation of LPS: +LPS group) [18]. The control group contained cells maintained in culture medium (DMEM). After an incubation period of 24 hours, the cells were immediately subjected to the MTT formazan assays and measurements of the production of nitric oxide (NO) and ROS. This study was repeated twice using 5 samples for each group at every time point.

\section{Cell viability assay}

In all cell models, the cell viability was evaluated 24 hours after the treatment with NCs. MTT solution (Sigma-Aldrich) $(5 \mathrm{mg} / \mathrm{mL})$ was added to each well, and cells were incubated at $37^{\circ} \mathrm{C}$ for 4 hours. The supernatant was removed, and then $100 \mu \mathrm{L}$ of DMSO (LGC Biotecnologia) was added. The optical density at $570 \mathrm{~nm}$ was then measured using a microplate reader (Biochrom, Cambridge, UK). The absorbance value readings were normalized to those of untreated control cultures (DMEM-100\%), and differences between the mean values were statistically analyzed.

\section{NO production}

NO production in the cell culture supernatants of hDPCs was quantified spectrophotometrically 24 hours after the treatment with the NCs and stimulation with LPS, using the diazotization reaction with Griess reagent. In this method, nitrite is first treated with sulfanilamide in acidic medium, followed by the addition of $\mathrm{N}$-naphthylethylenediamine. In a 96-well plate, $100-\mu \mathrm{L}$ aliquots of the supernatant of each sample were plated in quintuplicate with the same quantity of Griess reagent. After 10 minutes of incubation at ambient temperature protected from light, the absorbance was determined in a microplate reader with a $540 \mathrm{~nm}$ filter. The absorbance of this reaction at $540 \mathrm{~nm}$ is linearly proportional to the nitrite concentration in the samples. The positive control group contained LPS-stimulated cells without treatment, and the negative control group contained cells maintained in DMEM (no LPS stimulation).

\section{ROS production}

ROS production was quantified and evaluated qualitatively by means of the fluorescent oxidantsensing probe $2^{\prime}, 7^{\prime}$-dichlorodihydrofluorescein diacetate (DCFH-DA, Invitrogen). After a 24-hour incubation period with the NCs and stimulation with LPS, the medium was removed, and a solution containing the fluorescent probe in PBS $(5 \mu \mathrm{mol} / \mathrm{L})$ was added $(200 \mu \mathrm{L})$. After 5 minutes, inflammatory mediator expression was measured using a multimode plate reader (GloMax ${ }^{\circledast}$ Discover Multimode Microplate Reader, Promega, São Paulo, SP, Brazil). In the 
qualitative analyses, the samples were plated on 24 -well plates $\left(10^{5}\right.$ cells/well $)$ in the bottom of the compartments, and the same protocol was followed. After 24 hours, the culture medium was removed, and the samples were analyzed and photographed by fluorescence microscopy (Invitrogen Evos FL Imaging System, Invitrogen). The value readings were normalized to LPS control cultures (LPS-100\%), and the differences between mean values were statistically analyzed. The positive control group contained LPS-stimulated and untreated cells, and the negative control group contained cells maintained in DMEM (no LPS stimulation).

\section{Statistical analysis}

All data were analyzed for normality using the Kolmogorov-Smirnov test. One-way analysis of variance and the Tukey test were used to compare data between the treated groups. The Dunnett test was used to compare the experimental groups with the control group. Statistical significance was set at $\alpha=0.05$. Statistical analysis was performed using GraphPad Prism 6 software (GraphPad, La Jolla, CA, USA).

\section{RESULTS}

\section{Characterization of the nanocomposite}

The changes in the crystal lattice in terms of the type and percentage of crystals were evaluated by X-ray diffractograms of the samples, as shown in Figure 1. The X-ray diffractograms showed Bragg diffraction peaks characteristic of $\mathrm{ZnO}$ in the wurtzite structure (JCPDS: 36-1451), confirming the formation of ZnO NCs (Figure 1A). With increasing concentrations of $\mathrm{Ca}$, we observed a shift in the diffraction peak (100) to smaller angles

(Figure 1B). This displacement was related to the substitutional incorporation of the $\mathrm{Zn}^{2+}$ by

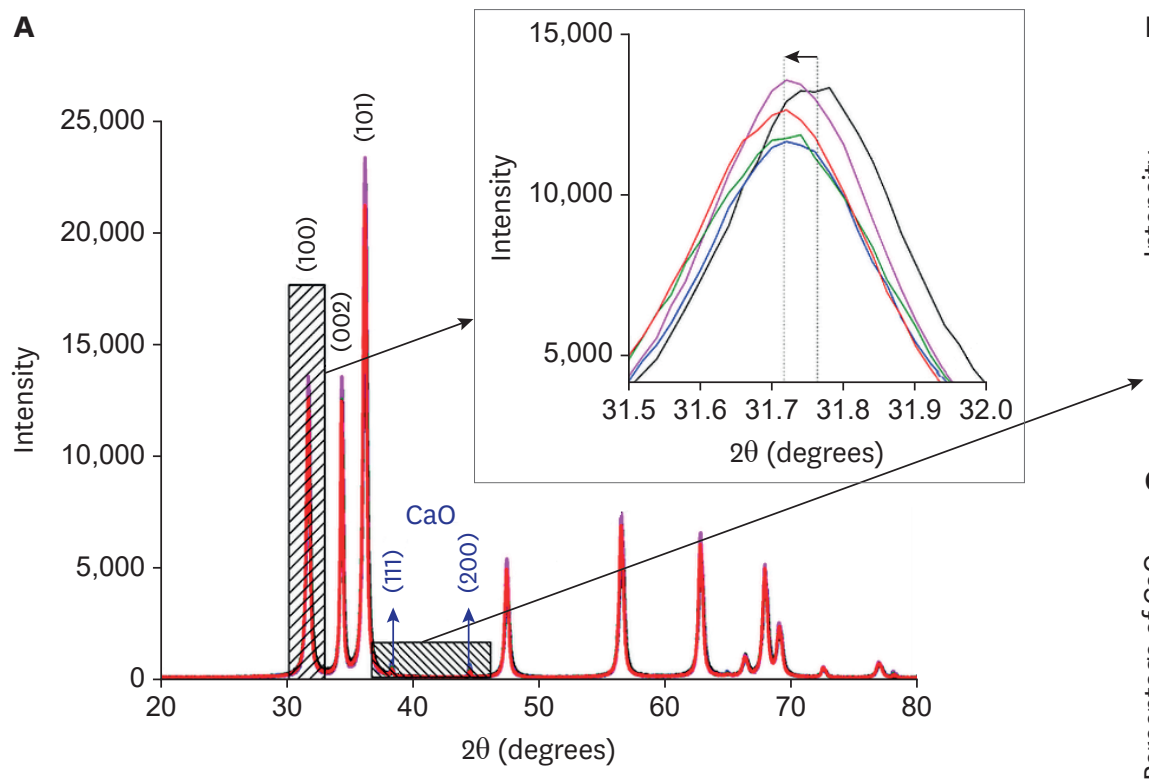

B

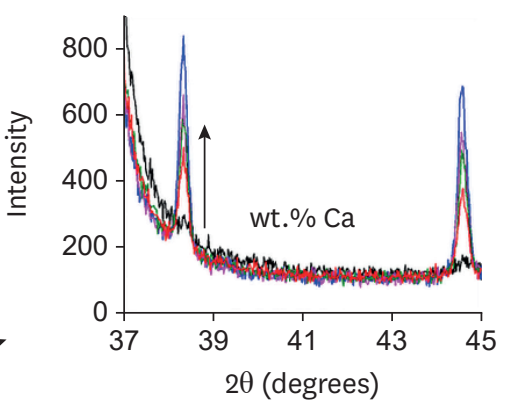

C

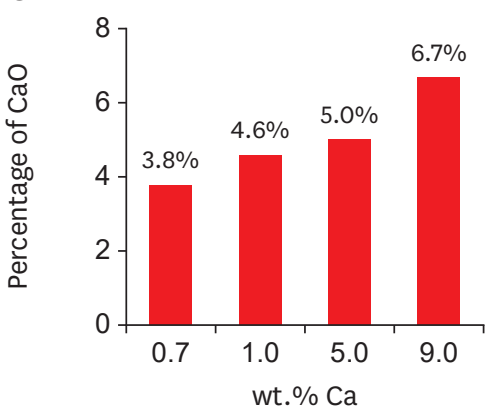

Figure 1. X-ray diffractograms of the zinc oxide (ZnO):calcium (xCa) nanocrystals. X-ray diffraction patterns of pure and Ca-doped ZnO nanocrystals (A), variation in angular distance confirming the incorporation of $\mathrm{Ca}^{2+}$ ions into $\mathrm{ZnO}$ nanocrystals (B), calcium oxide (CaO) nanocrystal patterns observed in $0.7 \mathrm{wt} . \% \mathrm{Ca}(\mathrm{C})$, increase in the concentration of $\mathrm{CaO}$ with Ca doping, from $3.8 \%$ to $6.7 \%$ for the 0.7 to $9.0 \mathrm{wt} . \%$ samples (C). 
$\mathrm{Ca}^{2+}$ ions in the crystalline structure of $\mathrm{ZnO}$, since the ionic radius of $\mathrm{Ca}^{2+}(0.99 \AA)$ is larger than that of $\mathrm{Zn}^{2+}(0.74 \AA)$. Moreover, the presence of Bragg diffraction peaks characteristic of CaO NCs (JCPDS: 00-037-1497) were observed beginning at the 0.7Ca concentration and intensified with increasing Ca concentrations in the samples, from 3.8\% to 6.7\% for samples from $0.7 \%$ to $9.0 \% \mathrm{Ca}$ (Figure 1C). Figure 1C illustrates samples in which $\mathrm{CaO}$ NCs formed as nanocomposites (Ca-doped $\mathrm{ZnO}+\mathrm{CaO} \mathrm{NCs}$ ).

The incorporation of ions into the crystalline structure can change the morphology, so the morphological properties of the samples were investigated by SEM with EDS (Figure 2). The SEM images showed greater quantities of ZnO NCs (Figure 2A) with a spherical morphology,

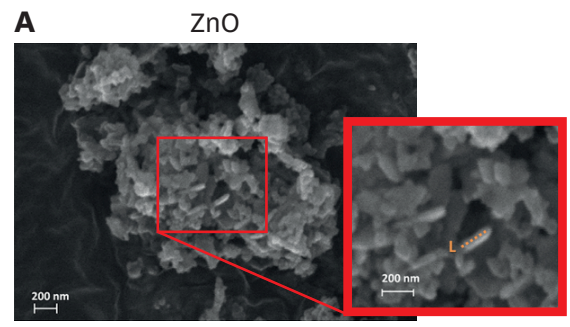

B

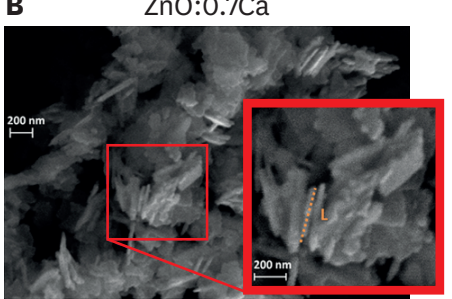

D

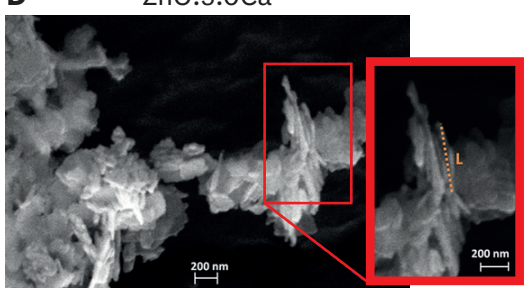

C ZnO:1.0Ca

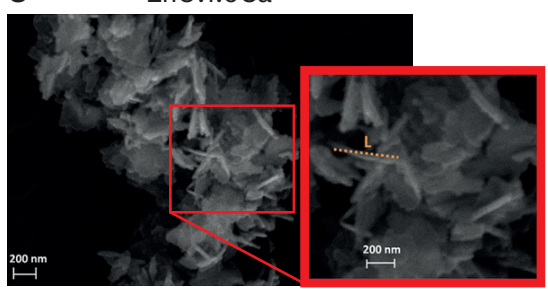

E Zno:9.0Ca

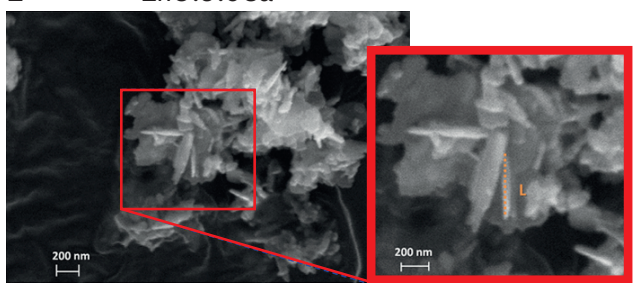

F
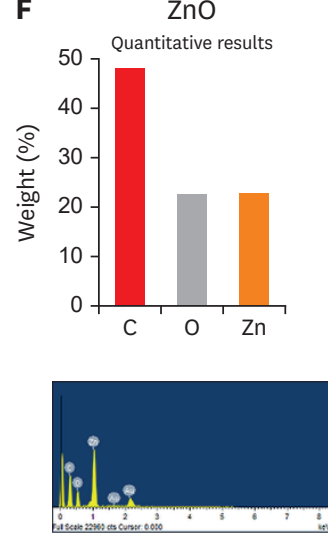

$0.7 \mathrm{Ca}$
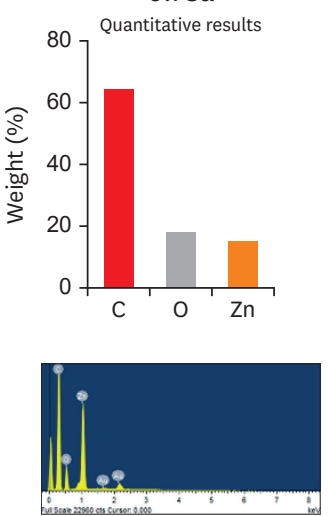
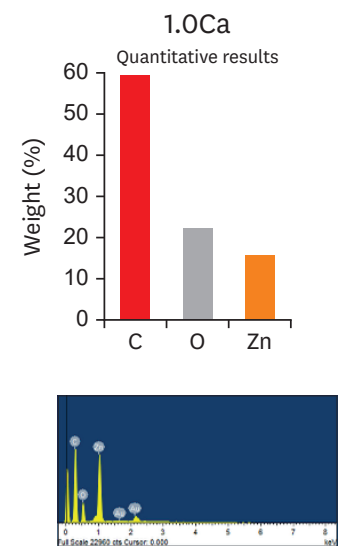

$5.0 \mathrm{Ca}$
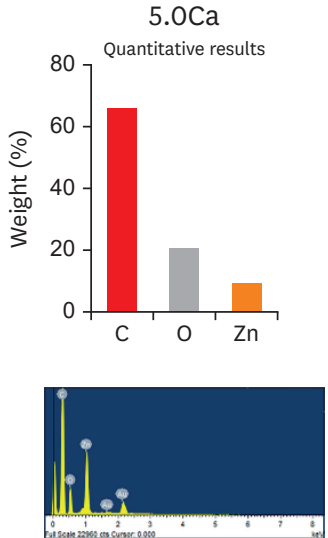

$9.0 \mathrm{Ca}$
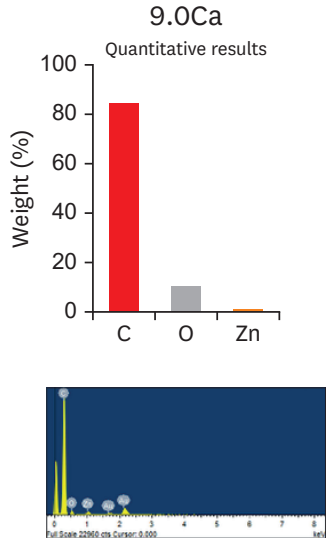

Figure 2. Scanning electron microscopy and energy dispersive X-ray spectrometry (EDS) results of the zinc oxide (ZnO):calcium (xCa) nanocrystals. ZnO nanocrystals (A) with spherical morphology predominated. In the rod-shaped nanocrystals, the rod length grew with the incorporation of Ca (B-E). In EDS, only $\mathrm{Zn}$ and $\mathrm{O}$ atoms were observed $(\mathrm{F})$. 


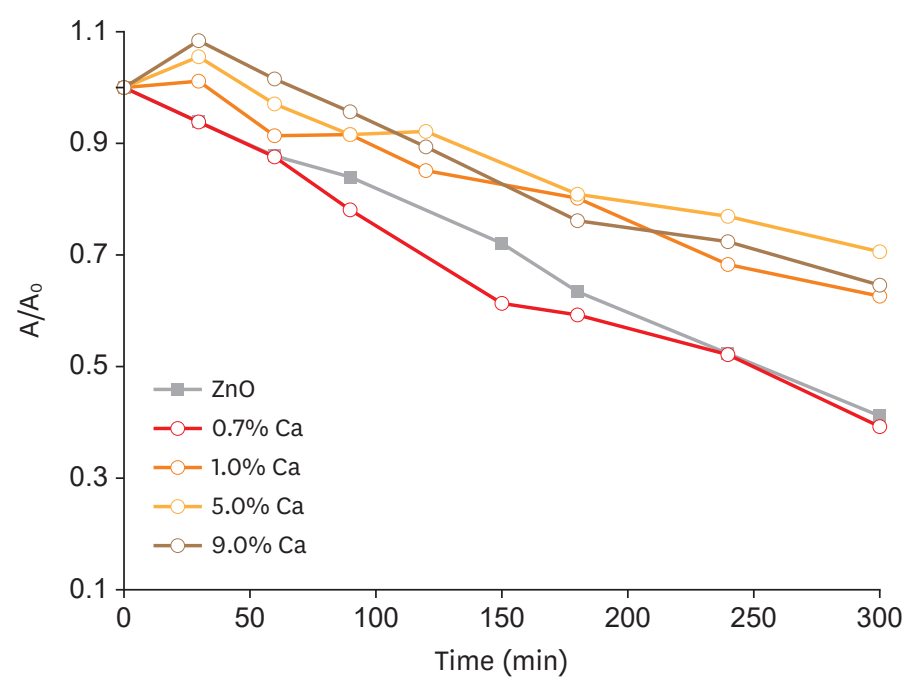

Figure 3. Methylene blue degradation in aqueous solution and ultraviolet-visible (UV-Vis) light irradiation of the zinc oxide ( $\mathrm{ZnO})$ :calcium ( $\mathrm{xCa}$ ) nanocrystals.

$A$, the absorbance of the solution at time $>0 ; A_{0}$, the initial absorbance.

with a few NCs exhibiting a rod shape. However, the incorporation of Ca into the $\mathrm{ZnO}$ structure favored an increased length of the rod shape (Figure 2B-E). The rod length was $160,200,300,400$, and $350 \mathrm{~nm}$ in the samples of pure $\mathrm{ZnO}$ and $\mathrm{ZnO}$ with $0.7 \% \mathrm{Ca}, 1.0 \%$ $\mathrm{Ca}, 5.0 \% \mathrm{Ca}$, and $9.0 \% \mathrm{Ca}$, respectively. This result indicates that $\mathrm{Ca}^{2+}$ ions were being incorporated into the sides of the crystal to favor growth in length. Regarding diameter, the following values were obtained: $50 \mathrm{~nm}(\mathrm{ZnO}), 30 \mathrm{~nm}(0.7 \% \mathrm{Ca})$, and $20 \mathrm{~nm}(1.0 \% \mathrm{Ca})$, and the same values were maintained for the samples of $5.0 \%$ and $9.0 \% \mathrm{Ca}$. These results reinforce the XRD findings (Figure 1), confirming the incorporation of $\mathrm{Ca}^{2+}$ ions into the crystalline structure of $\mathrm{ZnO}$. The quantity of spherical NCs was observed to increase; however, the average size remained approximately $50 \mathrm{~nm}$. The EDS results revealed only $\mathrm{Zn}$ and $\mathrm{O}$ atoms (Figure 2F). There were no Ca atoms in the results of EDS due to the low percentage of $\mathrm{CaO}$ formed in the sample, as demonstrated in the XRD results (Figure 1). The presence of $\mathrm{C}$ and $\mathrm{Au}$ atoms was related to the sample port and metallization, respectively. Formation of $\mathrm{CaO}$ was found to have occurred on the basis of variations in the proportion of $\mathrm{Zn}$ relative to $\mathrm{O}$. For example, in the sample of $\mathrm{ZnO}$, the ratio between $\mathrm{Zn}$ and $\mathrm{O}$ was 1:1, confirming the formation of pure $\mathrm{ZnO}$, since $1 \mathrm{Zn}^{2+}$ ion is required for $1 \mathrm{O}^{2-}$. In the doped samples, there was a relative increase in the percentage of $\mathrm{O}$, indicating the formation of some compound containing $\mathrm{O}$, which was $\mathrm{CaO}$ NCs based on the results of XRD.

The photocatalytic activity and percentage discoloration of these samples were examined through $\mathrm{MB}$ degradation in aqueous solution at $25^{\circ} \mathrm{C}$ using UV-Vis light irradiation, as shown in Figure 3. After UV-Vis irradiation for 5 hours, the MB degradation was found to be $59 \%$, $61 \%, 37 \%, 29 \%$, and $37 \%$ in samples of pure $\mathrm{ZnO}$ and $\mathrm{ZnO}$ with $0.7,1.0,5.0$ and $9 \mathrm{wt} . \% \mathrm{Ca}$, respectively.

\section{Biological assays}

1. SAOS-2 cytotoxicity

The cytotoxicity of NCs on SAOS-2 based on the MTT formazan assay is shown in Figure 4. At $10 \mu \mathrm{g} / \mathrm{mL}, \mathrm{ZnO}, \mathrm{ZnO}: 0.7 \mathrm{Ca}$ and $\mathrm{ZnO}: 1.0 \mathrm{Ca}$ had the highest percentages of cell viability $(p<0.05)$ (Figure 4A). At $50 \mu \mathrm{g} / \mathrm{mL}, \mathrm{ZnO}: 1.0 \mathrm{Ca}$ demonstrated higher viability than all 


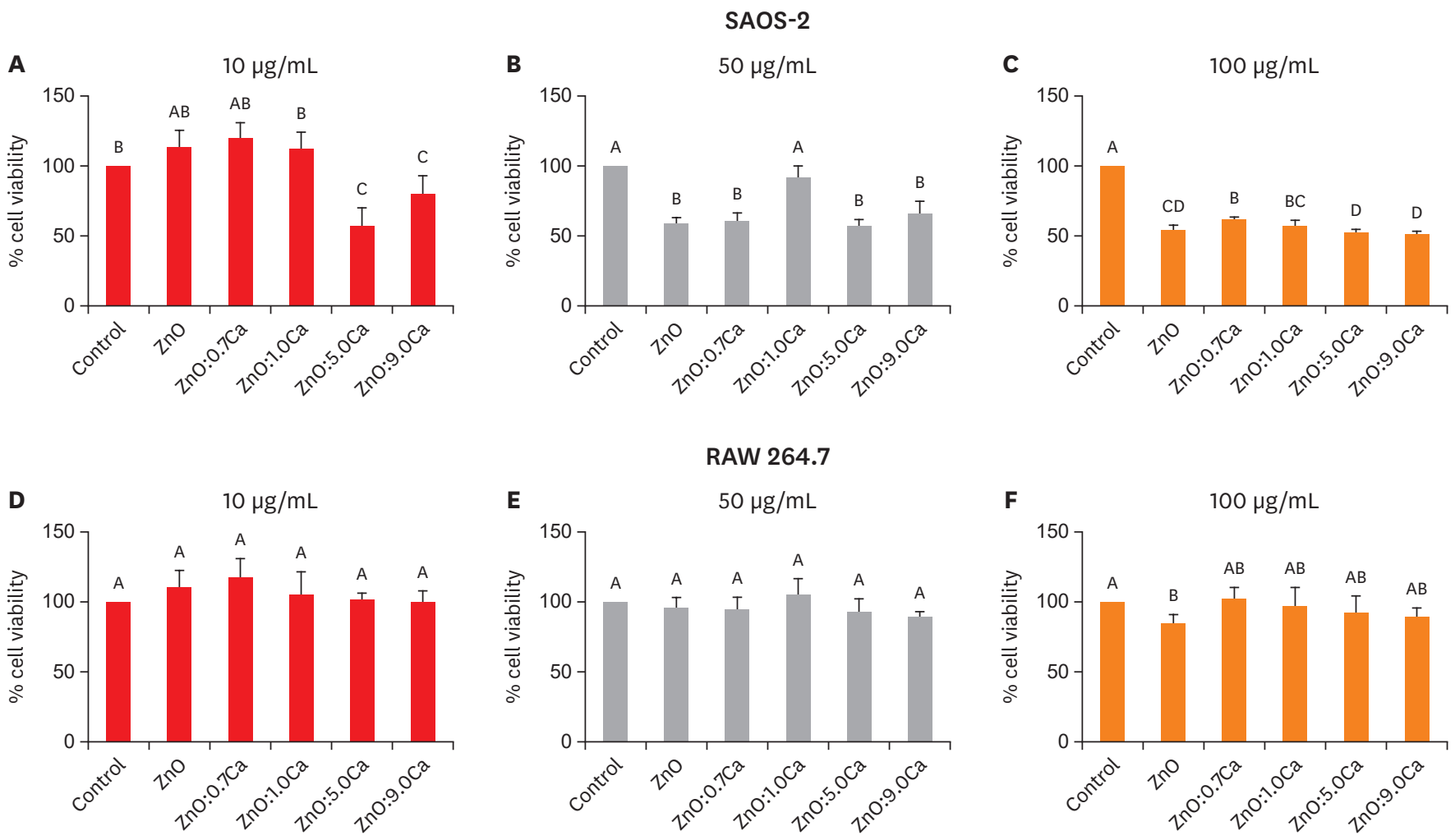

Figure 4. Cell viability determination of SAOS-2 and RAW 264.7 after treatment with zinc oxide (ZnO), ZnO:0.7 calcium (Ca), ZnO:1.0Ca, ZnO:5.0Ca and ZnO:9.0Ca by the MTT formazan assay. (A-C) The effects of nanoparticles at the concentrations of $10 \mu \mathrm{g} / \mathrm{mL}, 50 \mu \mathrm{g} / \mathrm{mL}$, and $100 \mu \mathrm{g} / \mathrm{mL}$, respectively, on SAOS-2 viability. (D-F) The effects of nanoparticles at the concentrations of $10 \mu \mathrm{g} / \mathrm{mL}, 50 \mu \mathrm{g} / \mathrm{mL}$, and $100 \mu \mathrm{g} / \mathrm{mL}$, respectively, on RAW 264.7 viability. Capital letters allow comparisons among different nanocrystals and with the control group (Dulbecco's Modified Eagle's Medium).

the experimental groups ( $p<0.05$ ) (Figure 4B). At $100 \mu \mathrm{g} / \mathrm{mL}, \mathrm{ZnO}: 0.7 \mathrm{Ca}$ and $\mathrm{ZnO}: 1.0 \mathrm{Ca}$ presented higher values of cell viability than $\mathrm{ZnO}$ :5.0Ca and $\mathrm{ZnO}$ :9.0Ca $(p<0.05)$ (Figure 4C). Compared with the control group, $\mathrm{ZnO}: 5.0 \mathrm{Ca}$ and $\mathrm{ZnO}: 9.0 \mathrm{Ca}$ had a lower percentage of cell viability at $10 \mu \mathrm{g} / \mathrm{mL}(p<0.05)$ (Figure $4 \mathrm{~A})$. All groups presented a lower percentage of viability at $50 \mu \mathrm{g} / \mathrm{mL}$ (Figure 4B) and $100 \mu \mathrm{g} / \mathrm{mL}$ (Figure 4C) than the control group ( $p<0.05$ ), except $\mathrm{ZnO}: 1.0 \mathrm{Ca}$ at $50 \mu \mathrm{g} / \mathrm{mL}$, which showed a similar value $(p>0.05)$.

\section{RAW 264.7 cytotoxicity}

The cytotoxicity of NCs on RAW 264.7 cells by the MTT formazan assay is shown in Figure 4. All groups evaluated had similar viability percentages among themselves $(p>0.05)$ and compared with the control $(p>0.05)$, regardless of the concentration evaluated (Figure 4D-F), except for the $\mathrm{ZnO}$ group at $100 \mu \mathrm{g} / \mathrm{mL}$ (Figure 4F), which presented lower cell viability than the control $(p>0.05)$.

\section{3. hDPC cytotoxicity}

The cytotoxicity of NCs on hDPCs based on the MTT formazan assay is shown in Figure 5. In the absence (-LPS) and presence of LPS (+LPS), all the groups presented lower viability levels than that of the control $(p<0.05)$. All the groups evaluated had similar viability percentages among themselves $(p>0.05)$. 


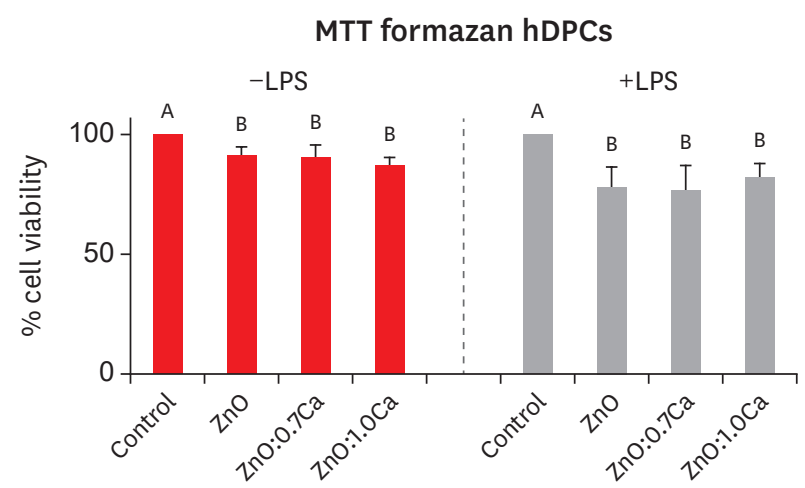

Figure 5. Cell viability determination of human dental pulp cells (hDPCs) after treatment with zinc oxide (ZnO), ZnO:0.7 calcium ( $\mathrm{Ca}$ ) and ZnO:1.0Ca by the MTT formazan assay. Effects of nanocrystals at the concentrations of $10 \mu \mathrm{g} / \mathrm{mL}$ on lipopolysaccharide-nonstimulated (-LPS) and -stimulated (+LPS) hDPCs. Capital letters allow comparisons among different nanocrystals for the same condition (-LPS or +LPS) and with control groups (positive control group: +LPS; and negative control group: Dulbecco's Modified Eagle's Medium, -LPS).

\section{Quantification of NO production}

Figure 6 presents the amount of $\mathrm{NO}$ produced by hDPCs after treatment with $\mathrm{ZnO}, \mathrm{ZnO}: 0.7 \mathrm{Ca}$, and ZnO:1.0Ca NCs considering LPS stimulation (+LPS) or nonstimulation (-LPS). Both in the absence and presence of LPS stimulation, NO production by hDPCs treated with NCs did not show statistically significant differences from the negative control group (DMEM) $(p>0.05)$. All the groups presented lower values than the positive control group $(+$ LPS $)(p<0.05)$.

\section{ROS production}

Figure 7 presents the amounts of ROS produced by hDPCs after treatment with $\mathrm{ZnO}$, ZnO:0.7Ca and ZnO:1.0Ca NCs considering LPS stimulation (+LPS) or nonstimulation (-LPS). In cells without LPS stimulation, $\mathrm{ZnO}$ :1.0Ca produced a higher amount of ROS than $\mathrm{ZnO}$ ( $p=$ $0.0281)$ and a similar amount to $\mathrm{ZnO}: 0.7 \mathrm{Ca}(p>0.05)$. In the presence of LPS, $\mathrm{ZnO}$ yielded similar amounts of ROS compared with ZnO:1.0Ca $(p>0.05)$ and higher percentages than $\mathrm{ZnO}: 0.7 \mathrm{Ca}(p=0.0065)$. All NCs induced the cells to produce higher amounts of ROS than was found in the negative control group (DMEM) $(p>0.05)$ and lower amounts than was found in the positive control group (LPS) $(p<0.0001)$.

\section{Griess method}

-LPS $\quad+$ LPS

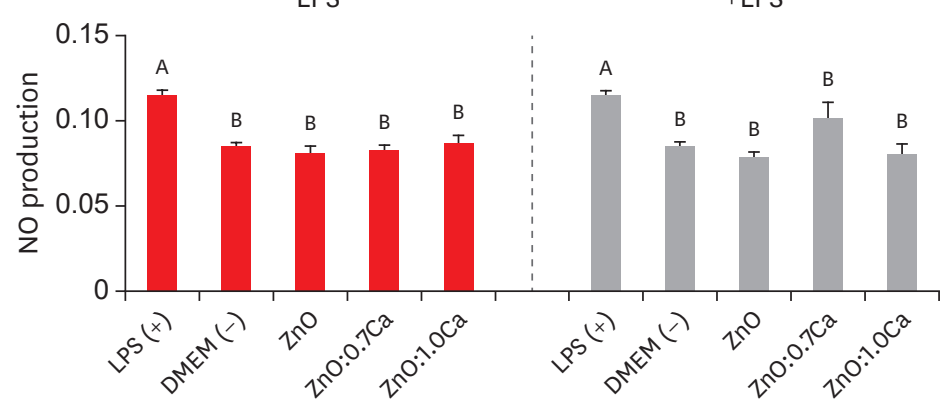

Figure 6. Nitric oxide (NO) production by lipopolysaccharide-nonstimulated (-LPS) and -stimulated (+LPS) human dental pulp cells (hDPCs) after treatment with zinc oxide (ZnO), ZnO:0.7 calcium (Ca), and ZnO:1.0Ca. The effects of nanocrystals at the concentration of $10 \mu \mathrm{g} / \mathrm{mL}$ on NO production in -LPS and +LPS hDPCs. Capital letters allow comparisons among different nanocrystals for the same condition (-LPS or +LPS) and with control groups (positive control group: +LPS; and negative control group: Dulbecco's Modified Eagle's Medium [DMEM], -LPS). 


\section{DCFH-DA}

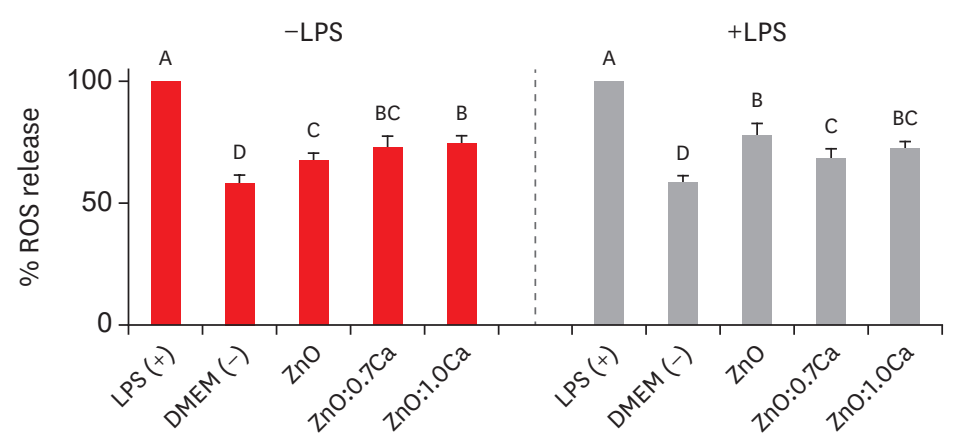

Figure 7. Reactive oxygen species (ROS) production by human dental pulp cells (hDPCs) after the treatment with zinc oxide (ZnO), ZnO:0.7 calcium (Ca), and ZnO:1.0Ca. The effects of nanocrystals at the concentration of $10 \mu \mathrm{g} /$ $\mathrm{mL}$ on ROS production in lipopolysaccharide-nonstimulated (-LPS) and -stimulated (+LPS) hDPCs. Capital letters allow comparisons among different nanocrystals for the same condition (-LPS or + LPS) and with control groups (positive control group: +LPS; and negative control group: Dulbecco's Modified Eagle's Medium [DMEM], -LPS). DCFH-DA, 2',7'-dichlorodihydrofluorescein diacetate.

According to the images generated by the application of the DCFH-DA probe, the exposure of hDPCs to LPS without NCs resulted in significantly higher ROS production than was found in the untreated group without LPS stimulation (Figure 8). In general, NC treatment of hDPCs

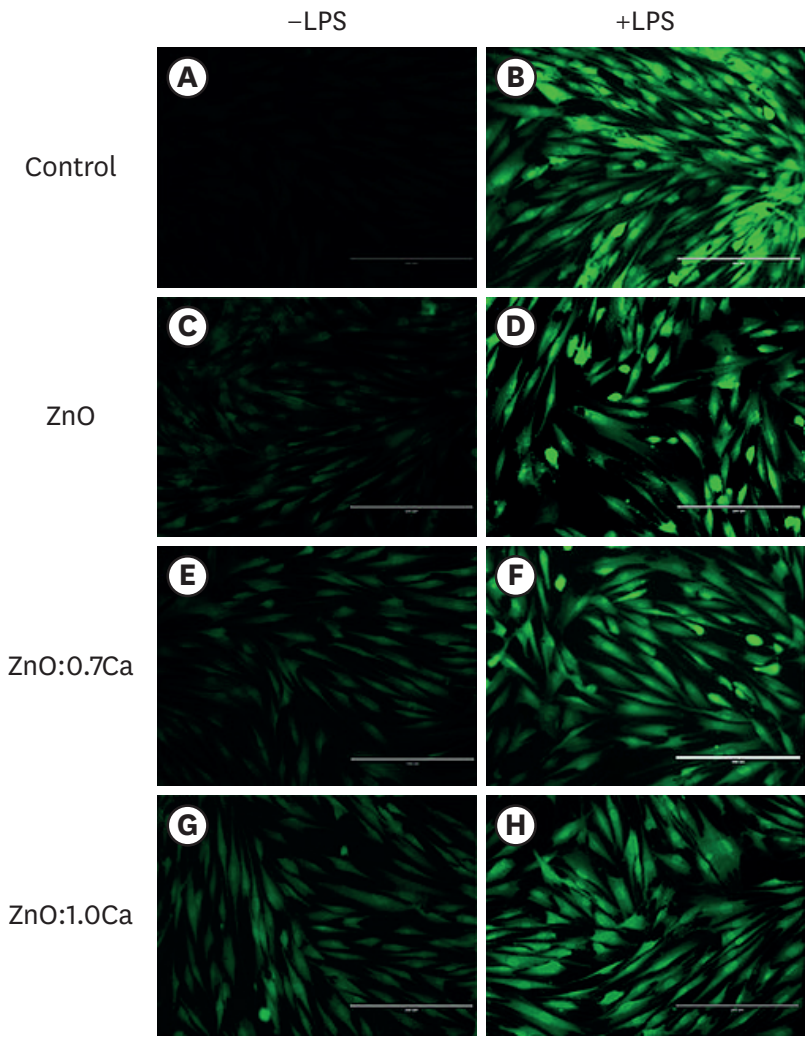

Figure 8. Images representative of reactive oxygen species (ROS) production by human dental pulp cells (hDPCs) treated with zinc oxide (ZnO), ZnO:0.7 calcium (Ca) and ZnO:1.0Ca. Images in the column on the left represent the groups in which the cells were notstimulated by lipopolysaccharide (-LPS), while in the images in the column on the right, the cells were kept in contact with LPS (+LPS). Dulbecco's Modified Eagle's Medium (DMEM) (A), LPS (B), ZnO (C, D), ZnO:0.7Ca (E, F), ZnO:1.0Ca (G, H). The intensity of fluorescence emitted by the $2^{\prime}, 7^{\prime}$-dichlorodihydrofluorescein diacetate (DCFH-DA) probe quantified ROS production, with higher fluorescence indicating higher levels of production of these oxidant agents. 
stimulated with LPS (Figure 8, column on the right), irrespective of the NP used, appeared to reduce ROS production in comparison to groups that were stimulated and not treated with NCs. For hDPCs that did not come into contact with LPS (Figure 8, column on the left), all the treatments with NCs were capable of increasing the quantity of ROS produced by the cells.

\section{DISCUSSION}

The results of the physical characterizations confirmed that ZnO NCs were synthesized and that increased $\mathrm{Ca}$ doping concentrations led to the formation of nanocomposite $\mathrm{Ca}$-doped $\mathrm{ZnO}$ with $\mathrm{CaO}$ NCs. The changes in crystal lattices in terms of the type and percentage of the synthesized materials were evaluated using XRD, which is often used to characterize new materials. To complement the XRD results, SEM images with EDS provided information on the microstructural and topographic features of the samples, in addition to a chemical analysis of the materials with qualitative and quantitative information. The SEM images confirmed that ZnO NCs with a spherical morphology predominated, with small amounts exhibiting a rod shape. The increase in doping concentration favored an increase in rod length, while NCs with spherical morphologies remained the same size. All the results confirmed the incorporation of $\mathrm{Ca}^{2+}$ ions into the crystalline structure of $\mathrm{ZnO}$ and the formation of $\mathrm{CaO}$ in samples doped with $\mathrm{Ca}$. Thus, in this work, a nanocomposite of Ca-doped $\mathrm{ZnO}$ and $\mathrm{CaO}$ NCs was formed.

Treatment with the evaluated NCs did not affect cell viability at lower concentrations, but at concentrations of $50 \mu \mathrm{g} / \mathrm{mL}$ and $100 \mu \mathrm{g} / \mathrm{mL}$, the viability was reduced. Studies have demonstrated different toxic effects associated with nanomaterials, including mitochondrial damage [19]. The MTT formazan assay is based on the conversion of yellow tetrazolium salt into dark blue formazan crystals by mitochondrial dehydrogenase activity [20]. However, it is important to note that nanomaterials containing reactive minerals forming antioxidants may interfere with the MTT assay, requiring additional methodologies to complement the results. The cell models selected for the first stage of this study were RAW 264.7 macrophage and SAOS-2 osteoblast cell lines. The choice of permanent cell lines or primary cell cultures as study models is controversial [21]. Although primary culture cells are obtained directly from the organism and therefore exhibit more faithful behavior [21], the use of immortalized cell cultures in a preliminary study assessing new materials is recommended in the literature $[22,23]$, and such cultures provide useful complementary systems for studying normal cells.

In this way, after determining the most cytotoxic concentrations by assessing the viability of immortalized cultures, which served as an initial screening, we opted for the less cytotoxic concentrations for tests in primary hDPC cultures, as these cells are more sensitive. In general, the results of the cell viability tests indicated that the less cytotoxic NCs were $\mathrm{ZnO}$, $\mathrm{ZnO}: 0.7 \mathrm{Ca}$, and $\mathrm{ZnO}: 1.0 \mathrm{Ca}$ at $10 \mu \mathrm{g} / \mathrm{mL}$, while cells treated with NCs containing the highest percentage of calcium in their composition $(5.0 \% \mathrm{Ca}$ and $9.0 \% \mathrm{Ca}$ ) showed the lowest cell viability values. This result demonstrates that higher concentrations of $\mathrm{CaO}$ favored the cytotoxicity of the nanocomposite. Calcium ion $\left(\mathrm{Ca}^{2+}\right)$ plays multiple important roles in cellular functions, acting as a secondary messenger that controls cellular responses and mediates physiological pathways, including cell death pathways [24]. The scientific literature states that when the mechanism of homeostasis of $\mathrm{Ca}^{2+}$ signaling is disturbed, cells can die via apoptosis or necrosis [25]. An overload of extracellular $\mathrm{Ca}^{2+}$ may increase its intracellular concentration, but the cell response can differ depending on whether the calcium signal develops as a local or a global change [24]. 
Another mechanism related to the cytotoxicity of cells treated with $5.0 \% \mathrm{Ca}$ and $9.0 \% \mathrm{Ca}$ is the high percentage of doping of these NCs. The increase in doping percentage alters the physical properties of NCs, such as their size, as demonstrated in the SEM images. These properties can lead to a greater internalization of the doped NCs inside the cell and interactions with proteins and biomolecules related to the production of ROS and cellular apoptosis [23], increasing the cytotoxicity, as observed in the present study. The large amounts of ROS are mainly attributed to the larger surface area, an increase in oxygen vacancies, and the diffusion ability of the reactant molecules [17]. Oxygen vacancies can act as electron capturing centers, which prevent the combination of photogenerated electrons $\left(\mathrm{e}^{-} \mathrm{CB}\right)$ and holes $\left(\mathrm{h}^{+} \mathrm{VB}\right)$ and promote photocatalytic ability [26]. Ca was proposed to enter the $\mathrm{B}$ site of $\mathrm{BaTaO}_{2} \mathrm{~N}$, (i.e., $\mathrm{BaCa}_{\mathrm{x} / 3} \mathrm{Ta}_{1-\mathrm{x} / 3} \mathrm{O}_{2+\mathrm{y}} \mathrm{N}_{1-\mathrm{y}} ; \mathrm{O} \leq \mathrm{x}, \mathrm{y}$ $\leq 1)$ and to successfully gain control over its defective levels (e.g., $\mathrm{Ta}^{4+}$ species) and band gap to improve photocatalysis [22]. Another study reported that the excellent degradation dye activities of $\mathrm{Ca}$ (II)-doped $\mathrm{In}_{2} \mathrm{~S}_{3}$ were mainly attributed to the large amount of effective reactive species such as $\mathrm{h}^{+}$and $\mathrm{O}_{2}^{-}[27]$.

Oxygen vacancies acted as active centers and were the main cause of the difference in photocatalytic activities for $\mathrm{Mg}$, $\mathrm{Ca}$ and $\mathrm{Y}$-doped $\mathrm{ZnO} / \mathrm{La}_{2} \mathrm{O}_{3}$ samples of varying morphologies [28]. Thus, based on the literature, the Ca sample of $0.7 \mathrm{wt} . \%$ was determined to have the highest photocatalytic activity. The introduction of higher levels of Ca (more than $0.7 \mathrm{wt} . \%$ Ca) had negative effects on both photocatalytic activity and stability, probably due to the rapid decrement of visible light absorbance and the increment of the level of defects [22]. Excess defects can act as recombination centers for electron and hole pairs. Radical oxidative species, such as $\mathrm{OH}^{-}$and $\mathrm{O}_{2}^{-}$, generated on the surface of catalysts are responsible for the degradation of $\mathrm{MB}$. The $0.7 \mathrm{wt} . \%$ Ca sample showed an MB degradation of $61 \%$, which was greater than that of $\mathrm{ZnO}(59 \%)$, indicating that synergistic effects between NCs might intensify the photocatalytic activity. The diminution of $\mathrm{MB}$ degradation in the $1.0 \%, 5.0 \%$, and $9.0 \%$ Ca samples (37\%, 29\%, and 35\%, respectively) occurred because the percentage of $\mathrm{CaO}$ was higher than in the other samples that disfavored photocatalysis.

hDPCs were chosen for the second experimental stage in order to test the least cytotoxic doping concentrations in a heterogeneous cell model that represented the site where the material is intended to be used. These cells can be obtained from dental pulp explants or by digestion of dental pulp tissue from exfoliated deciduous or permanent teeth [29]. For this study, pulp cells were isolated from primary teeth because it has been suggested that these cells show a better response than those from permanent teeth [30]. In addition, the nanomaterial tested has potential use in pulpotomies. Taking into account that most pulpotomies in deciduous teeth occur due to caries, it was crucial to simulate the inflammatory environment using LPS. Therefore, the $\mathrm{ZnO}, \mathrm{ZnO}: 0.7 \mathrm{Ca}$, and $\mathrm{ZnO}: 1.0 \mathrm{Ca}$ groups were placed in contact with stimulated and nonstimulated pulp cells.

LPS is an endotoxin that makes up the cell wall of Gram-negative bacteria and is capable of stimulating the production of several inflammatory mediators. It is therefore involved in the development of pulp inflammation. In this study, we chose to use E. coli LPS based on Montoro et al. [18]. The concentration of $50 \mu \mathrm{g} / \mathrm{mL}$ was chosen based on the findings of a previous pilot experiment regarding cell proliferation and the production of ROS. Although the concentration was higher than that found in the current literature, the determination of LPS concentrations in studies involving biomaterials must be defined individually in order to guarantee its effectiveness in inducing cell stress. LPS can stimulate the production of many cytokines in hDPCs, including the well-known inflammatory mediators IL-1B and IL-6 
[31,32]. Furthermore, LPS-induced cellular stress results in increased ROS $[18,33]$ and NO production $[18,34]$, as demonstrated in this study. Therefore, NO and ROS have been used as nonspecific markers of in vitro induction of inflammation [35]. Regarding both mediators, the treatment with LPS was considered as the positive control because it would tend to increase their production, whereas the nonstimulated cells had extremely low or undetectable values of ROS and NO.

NO is a cytotoxic, short-lived, reactive radical that is released in response to inflammatory cytokines and agents by a process involving NO synthase (NOS) [34]. Specifically, inducible NOS (iNOS) is activated by microbial products such as LPS [34]. Thus, hDPC cells that were not stimulated with LPS would not show an increase in NO production unless the tested NCs were capable of promoting a cytotoxic effect, which was confirmed by the present results. In the cells stimulated with LPS and treated with NCs, the NO levels were again not elevated, which demonstrated that all NCs were able to reduce NO production. These results are probably related to the observation that iNOS production involves a calciumindependent mechanism; that is, the binding of calmodulin to iNOS is tight even at low $\mathrm{Ca}^{2+}$ concentrations [34]. Therefore, the results were not related to the percentage of calcium present in the NCs.

Recent studies have shown that various NCs may be able to stimulate the production of ROS $[8,23,36]$, which was confirmed by the present findings in which all the tested NCs induced increased ROS production in the nonstimulated hDPCs, a finding that was most notable for ZnO:1.0Ca. In contrast, in the LPS-stimulated cells, treatment with NCs reduced ROS production, indicating that these NCs had the potential to inhibit the exacerbated response caused by the LPS stimulus, as the $\mathrm{ZnO}$ group presented lower values. These results are consistent with the fluorescence DCFH-DA probe images, which showed higher fluorescence in all groups treated with the NCs than in those without LPS treatment, as well as lower fluorescence intensity than the group without treatment and LPS stimulation. Moreover, a subtle increase in fluorescence intensity of the $\mathrm{ZnO}$ :1.0Ca group was detected in the cells without LPS and in the $\mathrm{ZnO}$ group in the cells with LPS. These results are in agreement with previous studies showing an increase in ROS levels after exposure to $\mathrm{ZnO}$ NCs at different concentrations, including $10 \mu \mathrm{g} / \mathrm{mL}$ [37,38]. Nevertheless, in these studies, hDPCs were not evaluated, and only the effects of the materials on cells without induced inflammation were observed.

The overall increase in ROS production might be related to the cytotoxicity of ZnO NCs. Two factors determine the cytotoxicity of ZnO NCs: (i) release of zinc ions $\left(\mathrm{Zn}^{2+}\right)$, and (ii) increased ROS production [39]. There is a proven relationship between oxidative stress, calcium homeostasis, and cell viability [40]. A previous study verified an inverse correlation between the intracellular level of $\mathrm{Ca}^{2+}$ and cellular viability $\left(\mathrm{R}^{2}=0.976\right)$, and between ROS and cell viability $\left(R^{2}=0.952\right)[40]$. The results of the present study support an inverse relationship between ROS and cell viability because all the groups treated with NCs presented lower viability than the untreated group, and the cell viability in the $\mathrm{ZnO}$ :1.0Ca group in non-LPSstimulated hDPCs and $\mathrm{ZnO}$ in stimulated cells was similar or lower to that observed in the negative controls.

Despite the limitations of the present research, it is important to emphasize that the NCs used in this study have not been evaluated previously. Therefore, this is an important preliminary study to define the specific physical characteristics of these NCs and the biological behavior of the cellular models used with these materials. However, more 
studies should be performed using another model of cell culture and molecular analyses to complement the present findings. In addition, the association of vehicles that provide adequate consistency and plasticity to the NC, allowing its insertion on the pulp, will be of fundamental importance in future studies.

\section{CONCLUSIONS}

Based on this data, we conclude that the NCs were successfully synthesized. The NCs tested at low concentrations were not cytotoxic to hDPCs. $\mathrm{ZnO}, \mathrm{ZnO}: 0.7 \mathrm{Ca}$, and $\mathrm{ZnO}$ :1.0Ca maintained NO production at basal levels, while ROS production was increased compared to the DMEM group. In LPS-stimulated cells, all NCs reduced the levels of ROS production compared with the LPS group, with better results for ZnO:0.7Ca. Therefore, synthesizing these results, ZnO:0.7Ca is appropriate for future studies evaluating pulp protection materials.

\section{ACKNOWLEDGMENTS}

This project was developed at CPBio - Biomechanics, Biomaterials and Cell Biology Research Center, Multiuser Laboratory of the Institute of Chemistry and Faculty of Chemical Engineering, both of the Federal University of Uberlândia.

\section{REFERENCES}

1. Cohenca N, Paranjpe A, Berg J. Vital pulp therapy. Dent Clin North Am 2013;57:59-73. PUBMED | CROSSREF

2. Landsiedel R, Fabian E, Ma-Hock L, van Ravenzwaay B, Wohlleben W, Wiench K, Oesch F. Toxico-/ biokinetics of nanomaterials. Arch Toxicol 2012;86:1021-1060. PUBMED | CROSSREF

3. Silva AC, Dantas NO, Silva MJ, Spanó MA, Goulart LR. Functional nanocrystals: towards biocompatibility, nontoxicity and biospecificity. In: Shrestha R, editor. Advances in biochemistry \& applications in medicine. Las Vegas, NV: Open Access eBooks; 2017. p1-27.

4. Costa e Silva LL, Cosme-Silva L, Sakai VT, Lopes CS, da Silveira AP, Moretti Neto RT, Gomes-Filho JE, Oliveira TM, da Silveira Moretti AB. Comparison between calcium hydroxide mixtures and mineral trioxide aggregate in primary teeth pulpotomy: a randomized controlled trial. J Appl Oral Sci 2019;27:e20180030 PUBMED | CROSSREF

5. de Melo Reis É, de Rezende AA, Santos DV, de Oliveria PF, Nicolella HD, Tavares DC, Silva AC, Dantas NO, Spanó MA. Assessment of the genotoxic potential of two zinc oxide sources (amorphous and nanoparticles) using the in vitro micronucleus test and the in vivo wing somatic mutation and recombination test. Food Chem Toxicol 2015;84:55-63. PUBMED | CROSSREF

6. Das M, Saxena N, Dwivedi PD. Emerging trends of nanoparticles application in food technology: safety paradigms. Nanotoxicology 2009;3:10-18. CROSSREF

7. Silva AC, Silva MJ, da Luz FA, Silva DP, de Deus SL, Dantas NO. Controlling the cytotoxicity of CdSe magic-sized quantum dots as a function of surface defect density. Nano Lett 2014;14:5452-5457. PUBMED | CROSSREF

8. Valdiglesias V, Kiliç G, Costa C, Fernández-Bertólez N, Pásaro E, Teixeira JP, Laffon B. Effects of iron oxide nanoparticles: cytotoxicity, genotoxicity, developmental toxicity, and neurotoxicity. Environ Mol Mutagen 2015;56:125-148.

PUBMED | CROSSREF 
9. Pilownic KJ, Gomes AP, Wang ZJ, Almeida LH, Romano AR, Shen Y, Felix AO, Haapasalo M, Pappen FG. Physicochemical and biological evaluation of endodontic filling materials for primary teeth. Braz Dent J 2017;28:578-586. PUBMED | CROSSREF

10. Gonzalez-Lara A, Ruiz-Rodriguez MS, Pierdant-Perez M, Garrocho-Rangel JA, Pozos-Guillen AJ. Zinc oxide-eugenol pulpotomy in primary teeth: a 24-month follow-up. J Clin Pediatr Dent 2016;40:107-112. PUBMED | CROSSREF

11. Söderberg TA, Sunzel B, Holm S, Elmros T, Hallmans G, Sjöberg S. Antibacterial effect of zinc oxide in vitro. Scand J Plast Reconstr Surg Hand Surg 1990;24:193-197. PUBMED | CROSSREF

12. Lipovsky A, Nitzan Y, Gedanken A, Lubart R. Antifungal activity of ZnO nanoparticles--the role of ROS mediated cell injury. Nanotechnology 2011;22:105101.

PUBMED | CROSSREF

13. Xia T, Zhao Y, Sager T, George S, Pokhrel S, Li N, Schoenfeld D, Meng H, Lin S, Wang X, Wang M, Ji Z, Zink JI, Mädler L, Castranova V, Lin S, Nel AE. Decreased dissolution of ZnO by iron doping yields nanoparticles with reduced toxicity in the rodent lung and zebrafish embryos. ACS Nano 2011;5:1223-1235. PUBMED | CROSSREF

14. Silva AC, Zóia MA, Correia LI, Azevedo FV, Paula AT, Maia LP, Carvalho LS, Carvalho LN, Costa MP, Giaretta LC, Rodrigues RS, Ávila VM, Goulart LR, Dantas NO. Biocompatibility of doped semiconductors nanocrystals and nanocomposites. In: Askin Celik T, editor. Cytotoxicity. London: IntechOpen; 2018. p149-161.

15. Adeleye AS, Pokhrel S, Mädler L, Keller AA. Influence of nanoparticle doping on the colloidal stability and toxicity of copper oxide nanoparticles in synthetic and natural waters. Water Res 2018;132:12-22. PUBMED | CROSSREF

16. Karthikeyan B, Pandiyarajan T, Mangaiyarkarasi K. Optical properties of sol-gel synthesized calcium doped ZnO nanostructures. Spectrochim Acta A Mol Biomol Spectrosc 2011;82:97-101. PUBMED | CROSSREF

17. Haja Hameed AS, Karthikeyan C, Sasikumar S, Senthil Kumar V, Kumaresan S, Ravi G. Impact of alkaline metal ions $\mathrm{Mg}^{2+}, \mathrm{Ca}^{2+}, \mathrm{Sr}^{2+}$ and $\mathrm{Ba}^{2+}$ on the structural, optical, thermal and antibacterial properties of $\mathrm{ZnO}$ nanoparticles prepared by the co-precipitation method. J Mater Chem B 2013;1:5950-5962. PUBMED | CROSSREF

18. Montoro LA, Turrioni AP, Basso FG, de Souza Costa CA, Hebling J. Infrared LED irradiation photobiomodulation of oxidative stress in human dental pulp cells. Int Endod J 2014;47:747-755. PUBMED | CROSSREF

19. Babele PK, Thakre PK, Kumawat R, Tomar RS. Zinc oxide nanoparticles induce toxicity by affecting cell wall integrity pathway, mitochondrial function and lipid homeostasis in Saccharomyces cerevisiae. Chemosphere 2018;213:65-75. PUBMED | CROSSREF

20. Mosmann T. Rapid colorimetric assay for cellular growth and survival: application to proliferation and cytotoxicity assays. J Immunol Methods 1983;65:55-63. PUBMED | CROSSREF

21. Honegger P. Overview of cell and tissue culture techniques. Curr Protoc Pharmacol 2001; Chapter 12:Unit12.1. PUBMED | CROSSREF

22. Wei S, Zhang G, Xu X. Activating BaTaO $2 \mathrm{~N}$ by Ca modifications and cobalt oxide for visible light photocatalytic water oxidation reactions. Appl Catal B 2018;237:373-381. CROSSREF

23. Das BK, Verma SK, Das T, Panda PK, Parashar K, Suar M, Parashar SK. Altered electrical properties with controlled copper doping in $\mathrm{ZnO}$ nanoparticles infers their cytotoxicity in macrophages by ROS induction and apoptosis. Chem Biol Interact 2019;297:141-154. PUBMED | CROSSREF

24. Wójcik-Piotrowicz K, Kaszuba-Zwoińska J, Rokita E, Thor P. Cell viability modulation through changes of $\mathrm{Ca}^{2+}$-dependent signalling pathways. Prog Biophys Mol Biol 2016;121:45-53. PUBMED | CROSSREF

25. Berridge MJ, Bootman MD, Roderick HL. Calcium signalling: dynamics, homeostasis and remodelling. Nat Rev Mol Cell Biol 2003;4:517-529. PUBMED | CROSSREF

26. Meng F, Liu Y, Wang J, Tan X, Sun H, Liu S, Wang S. Temperature dependent photocatalysis of g- $\mathrm{C}_{3} \mathrm{~N}_{4}$, $\mathrm{TiO}_{2}$ and $\mathrm{ZnO}$ : differences in photoactive mechanism. J Colloid Interface Sci 2018;532:321-330. PUBMED | CROSSREF 
27. Yang S, Xu CY, Zhang BY, Yang L, Hu SP, Zhen L. Ca(II) doped $\beta-\mathrm{In}_{2} \mathrm{~S}_{3}$ hierarchical structures for photocatalytic hydrogen generation and organic dye degradation under visible light irradiation. J Colloid Interface Sci 2017;491:230-237. PUBMED | CROSSREF

28. Li C, Hu R, Zhou T, Wu H, Song K, Liu X, Wang R. Special morphologies of Mg, Ca, and Y-doped ZnO/ $\mathrm{La}_{2} \mathrm{O}_{3}$ composite for photocatalysis. Mater Lett 2014;124:81-84. CROSSREF

29. Rodríguez-Lozano FJ, Bueno C, Insausti CL, Meseguer L, Ramírez MC, Blanquer M, Marín N, Martínez S, Moraleda JM. Mesenchymal stem cells derived from dental tissues. Int Endod J 2011;44:800-806. PUBMED | CROSSREF

30. Wang X, Sha XJ, Li GH, Yang FS, Ji K, Wen LY, Liu SY, Chen L, Ding Y, Xuan K. Comparative characterization of stem cells from human exfoliated deciduous teeth and dental pulp stem cells. Arch Oral Biol 2012;57:1231-1240. PUBMED | CROSSREF

31. Lai WY, Kao CT, Hung CJ, Huang TH, Shie MY. An evaluation of the inflammatory response of lipopolysaccharide-treated primary dental pulp cells with regard to calcium silicate-based cements. Int J Oral Sci 2014;6:94-98. PUBMED | CROSSREF

32. Kim DH, Jang JH, Lee BN, Chang HS, Hwang IN, Oh WM, Kim SH, Min KS, Koh JT, Hwang YC. Antiinflammatory and mineralization effects of ProRoot MTA and Endocem MTA in studies of human and rat dental pulps in vitro and in vivo. J Endod 2018;44:1534-1541. PUBMED | CROSSREF

33. Kim JC, Lee YH, Yu MK, Lee NH, Park JD, Bhattarai G, Yi HK. Anti-inflammatory mechanism of PPAR $\gamma$ on LPS-induced pulp cells: role of the ROS removal activity. Arch Oral Biol 2012;57:392-400. PUBMED | CROSSREF

34. Korhonen R, Lahti A, Kankaanranta H, Moilanen E. Nitric oxide production and signaling in inflammation. Curr Drug Targets Inflamm Allergy 2005;4:471-479. PUBMED | CROSSREF

35. Min KS, Hwang YH, Ju HJ, Chang HS, Kang KH, Pi SH, Lee SK, Lee SK, Kim EC. Heme oxygenase-1 mediates cytoprotection against nitric oxide-induced cytotoxicity via the cGMP pathway in human pulp cells. Oral Surg Oral Med Oral Pathol Oral Radiol Endod 2006;102:803-808. PUBMED | CROSSREF

36. El-Hussein A, Hamblin MR. ROS generation and DNA damage with photo-inactivation mediated by silver nanoparticles in lung cancer cell line. IET Nanobiotechnol 2017;11:173-178. PUBMED | CROSSREF

37. Zhang J, Song W, Guo J, Zhang J, Sun Z, Ding F, Gao M. Toxic effect of different ZnO particles on mouse alveolar macrophages. J Hazard Mater 2012;219-220:148-155. PUBMED | CROSSREF

38. Zhang R, Liu X, Xiong Z, Huang Q, Yang X, Yan H, Ma J, Feng Q, Shen Z. The immunomodulatory effects of $\mathrm{Zn}$-incorporated micro/nanostructured coating in inducing osteogenesis. Artif Cells Nanomed Biotechnol 2018;46:1123-1130. PUBMED | CROSSREF

39. Shen C, James SA, de Jonge MD, Turney TW, Wright PF, Feltis BN. Relating cytotoxicity, zinc ions, and reactive oxygen in $\mathrm{ZnO}$ nanoparticle-exposed human immune cells. Toxicol Sci 2013;136:120-130 PUBMED | CROSSREF

40. Huang CC, Aronstam RS, Chen DR, Huang YW. Oxidative stress, calcium homeostasis, and altered gene expression in human lung epithelial cells exposed to ZnO nanoparticles. Toxicol In Vitro 2010;24:45-55. PUBMED | CROSSREF 